\title{
STOCK PRICE REACTION TO DIVIDEND ANNOUNCEMENT IN CROATIA
}

\begin{abstract}
The aim of this research is to analyze the connection between dividend announcement and stock price on Croatian capital market using event study methodology. Research period was the period from the year 2007 to the year 2009. Results have confirmed that dividend change has statistically significant value for investors. Dividend increase and dividend decrease resulted with statistically significant stock price change in the same direction, while dividend retention resulted with no statistically significant stock price change.
\end{abstract}

Key words: dividend, dividend announcement, stock price, abnormal returns

\section{INTRODUCTION}

If there is information symmetry every participant has the same information about the company on market. If one participant or a group has superior information about company in comparison to other participants, information asymmetry exists on the market. A great number of economic theoreticians and investigators from finance believe that managers posses superior information about the company they run with respect to other participants on the market. Larger information asymmetry means larger probability of manager opportunistic behavior. Manager opportunism results in occurrence of the problem called hidden information problem. Hidden information problem presents the situation in which manager is in the advantage due to having hidden information other stockholders don't have and having the possibility to hide information. A possible solution of hidden information problem is signaling. Basis of the signaling theory is information asymmetry which exists on market and represents an unequal access to information between managers and stockholders. The presumption on which this theory is based is the possibility of reducing information asymmetry by dividends which are used by insiders when they want to signal company situation. The concept of signaling theory originates in the work of Lintner (1956), who demonstrated how stock price often reacts to dividend changes.

In their seminal paper Miller and Modigliani (1961) stated that dividend policy is irrelevant for company value, but they also stated that market perception about dividend change can influence stock price reaction. If the company has established dividend policy with long term dividend payout ratio, change in dividend payout ratio would be seen as change in management view of company prospect. Dividend change conveys information, based on which investors make revaluation of their investments. Simply stated, dividend initiation or increase conveys bullish information and as a consequence stock prices usually rise, while dividend omission or decrease conveys bearish information and stock prices usually decrease.

Information content of dividend change presents the object of this investigation while the goal is to investigate influence of unexpected dividend change on stock price. Scientific

\footnotetext{
* Lecturer, University centre for professional studies, Koplica 5, 21000 Split, mamiletic@oss.unist.hr
} 
literature reveals three methods used to test the ability of dividend to convey information. The type of approach depends on which of the following questions researcher wants to answer (Lease et al., 2000, 109):

1. Do unanticipated changes in dividends, when announced, cause stock price reaction to change in the same direction?

2. Are unanticipated announcements of changes in dividends accompanied by revisions in the market's expectations of future earnings in the same direction as the dividend change?

3. Do dividend changes predict future earnings beyond those predicted by past earnings?

This paper deals with the approach handling the first question. Research based on the second approach is not possible to accomplish because there is no revision of earnings forecast by an amount that is positively related to the size of the announced dividend change in Croatia. Stock market in Croatia is relatively new and it's not possible to do research of a longer period in time which could make the third approach relevant. Therefore, answering the second and the third question is not the subject of this paper.

The paper is organized as follows. Section 2 presents a brief literature review regarding dividend announcements. This is followed by a description of the data, hypothesis and methodology in Section 3. The empirical analysis of the relationship between dividend announcement and stock price reaction is described in Section 4. Last section is the conclusion.

\section{LITERATURE REVIEW}

In the second half of the $20^{\text {th }}$ century theoretical signaling models where developed. Among a large number of theoretical models several of them need to be mentioned. Bhattacharya's model (1979) is the one in which company with high-quality investment project will pay high dividend, while managers in company with not so quality projects won't be able to pay high dividend because payoffs from projects are not sufficient to cover high dividends and the company will resort to outside financing which involves transaction costs. According to Bhattacharya (1979), managers signal the quality of an investment projects by committing to a specific dividend policy. Another model is John and Williams' model (1985) based on adverse tax consequences of dividends. John and Long (1991) constructed a model based on insider trading around dividend announcement, where insider trading represents the main information in signaling mechanism. The basic idea of these models is management usage of dividends to signal private information about future prospects of company.

The idea according to which a dividend could be used as a signal of company's business is established among financial directors of large companies in the USA. Abrutyn and Turner (1990) made a survey of financial directors of large companies in the USA in which $63 \%$ of examinees stated signaling to be the first or the second most likely reason to make dividend payout. Companies initiate or increase dividends only when they are certain about the maintenance of their good business because they avoid dividend cuts or omission. Lintner (1956) and Fama and Babiak (1968) have found a relationship between dividend and earnings consistent with the hypothesis that companies which paid out dividend, increase the dividend only when management is convinced that it can be sustained in the future.

Petit (1972) was one of the first researchers who tried to investigate signaling theory via dividend change. He investigated the speed of market reaction on dividend change and concluded that stock price entirely reflect dividend change positively and negatively on the announcement day and the day after. Petit believes that market uses information conveyed in the announcement in a way that they question company's market value on the basis of this information. Asquitha and Mullins' (1983) research results show significant positive returns connected with initiation or new dividend payoff ten years after the preceding dividend 
payoff. Based on this research and a sample similar to the one taken by Asquitha and Mullins' (1983), Healy and Paelpu (1988) confirm results shown in Asquitha and Mullins (1983). Fuller and Goldstein (2004) made a research during economy rise and during economy decline. They stress that a signal that company is experiencing problems is company's dividend decrease during recession. Nevertheless, company's dividend decrease during market expansion has less information content than its dividend decrease during recession. Capsaff, Klæboe and Marshall (2004) made a research of dividend announcement impact on stock price in Norway. Research showed statistically relevant abnormal stock returns for unexpected increase and decrease of dividend payoff rate, whereas unchanged dividends resulted in statistically irrelevant negative changes which confirmed one of the conditions of signaling theory.

Kalay and Loewenstein (1986) claim that market adjusts to potentially negative information (dividend decrease) concerning the date when the information should be revealed to market and they stated how this price change (decrease) is lower for that negative information which was conveyed afterwards since market already gradually included potentially negative information in the price.

Besides announcement impact of unexpected dividend change on stock price, there are researches showing dividend announcement impact on stock turnover. Richardson, Sefcik and Thompson's (1986) research abnormal turnover increase linked to dividend change. They state that increased turnover is mainly connected with information dividend content. Besides abnormal turnovers, research results show an abnormal 4\% return caused by information about dividend initiation. Research made by Gurgul, Majdosz and Mestel (2006) was focused on investigating impact of dividend announcement change on stock price and turnover change on German capital market. Positive and negative dividend change had a statistically significant influence on price change in the same direction as the announcement. Research results show that dividend information represents new and valuable market information. Investors are informed differently and have differently valuable information (real information) so they react differently to new information which leads to significant turnover increase. According to Haw and Kim (1991), the change of dividend payoff rate has a greater impact on the perception of investor who owns stocks of smaller companies. The assumption is that information asymmetry is greater in smaller companies. Investors in larger companies are better known with the business of larger companies and they can anticipate better information content of dividend change, therefore, stock price of large companies already includes piece of information which needs to be conveyed with dividend change announcement.

Connection between dividend announcement and stock price was investigated on many markets in the world and by many authors but in Croatia, unlike the developed markets, connection between dividend announcement and stock price has not been investigated yet.

\section{SURVEY STRUCTURE}

\subsection{DATA}

Research period in survey dates from the beginning of year 2007 to end of year 2009, while basic population from which the sample is taken presents companies listed on Zagreb Stock Exchange. Regular and preferred stocks were taken in research. To enter the sample companies had to meet following three criteria (in sequence):

1. Companies had to announce dividend change in period 2007 - 2009 compared with year before announcement. In Croatia dividend amount is usually first time announce through General Meeting notice. Companies which announced special dividend in addition to 
regular cash dividend weren't taken in examination because this kind of dividends are often object of separate investigation with respect to regular dividends.

2. Next criterion was absence of any other unexpected significant information ${ }^{1}$ which could influence on stock price on the announcement day.

3. The third criterion was that minimum turnover in the year when dividend change was announced which had to be 50 million HRK. Companies which made turnover less than 50 million HRK weren't taken into consideration. The aim was to avoid one of flaws of the Croatian capital market by taking 50 million HRK as minimum turnover. The aforementioned flaw is a great number of illiquid stocks which are not subject of every day trading and in which small daily turnover can have huge effect on stock price.

In order to get consistent research results, stocks of companies fulfilling previously mentioned criteria need to be set in three groups. These groups need to be defined based on dividend announcement direction. Therefore, one group was consisted of companies which announced unexpected dividend increase, second group was consisted of companies which announced unexpected dividend decrease, and third of companies which announced payoffs of unchanged dividends. A naive model was used when defining increase, decrease or maintenance of the same dividend per stock. According to naive model, expected dividend in an observed year equals the dividend paid the previous year.

From year 2007 to year 200922 companies made 35 dividend increase announcements. In the same period 10 companies made 11 dividend decrease announcements while 9 companies made 10 announcements of unchanged dividend.

\subsection{HYPOTHESIS}

Information content of dividend change presents the problem of this investigation while the goal is to investigate influence of unexpected dividend change on stock price. On the basis of the goal of this research main hypothesis was set up and it reads:

\section{Croatian stock market.}

$H_{1}$ : Announcement of dividend change has significant value for investors on

Within the elaboration of the main hypothesis, dividend information value for investors is analyzed. Following this idea, according to the previous research in this area, the connection between dividend change and abnormal return is examined where abnormal return represents the difference between actual and expected return.

Since dividend change can have three directions; increase, decrease or maintenance of the same dividend amount, three backing hypotheses are being formed in order to confirm or to reject the main hypothesis.

$H_{1.1 .:}$ There is a statistically significant connection between unexpected dividend increase and positive abnormal return.

$H_{1.2 .}$ : There is a statistically significant connection between unexpected dividend decrease and negative abnormal return.

Unexpected dividend increase or decrease represents relevant information for the market based on which decisions about investment are made, while unexpected dividend doesn't represent relevant information and, therefore, the third backing hypothesis is:

$H_{1.3}$ : There is no statistically significant relationship between unchanged dividend and abnormal return.

\footnotetext{
${ }^{1}$ e.g. announcement of recapitalization can have significant influence on stock price.
} 


\subsection{METHODOLOGY}

Event study was used to investigate stock price reaction to dividend announcement in the paper. Event study is a commonly used method when examining stock market reaction to dividend announcement, but there is no single "best" methodological approach for an event study. Analysis period of 40 days is used in the conducted event study. Accordingly to Johnson (1998) a comparison period of 30 days gives the best results in the event study and that period is used in survey. Announcement period was 10 days. It was consisted of seven days before the event date, event day (day of the dividend announcement) and two days after dividend announcement. Figure 1 presents analysis period which was used for analyzing relationship between dividend announcement and stock price reaction.

\section{Figure 1}

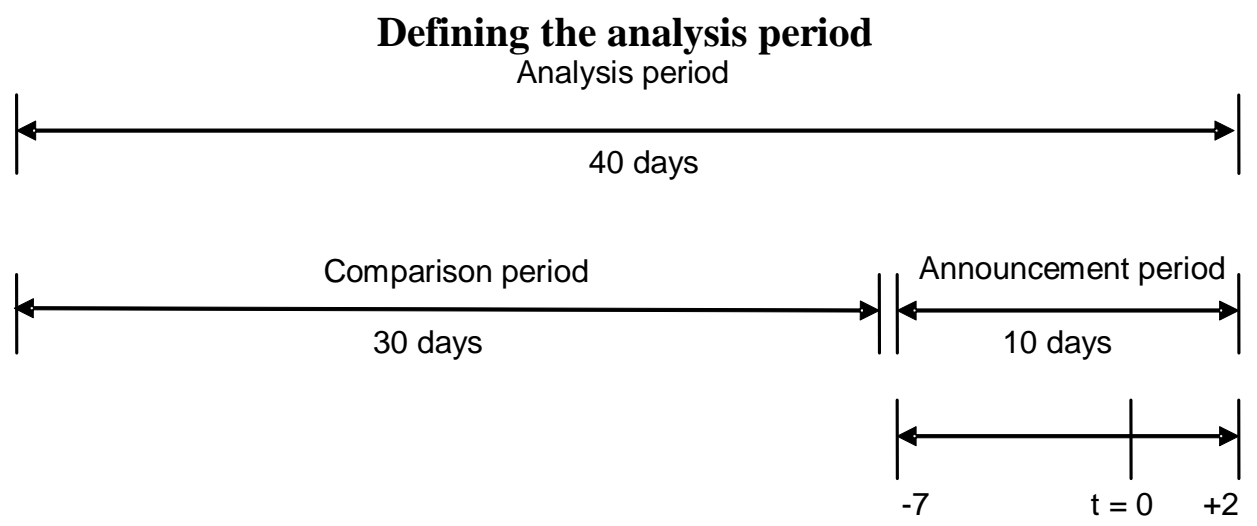

In order to examine return behavior of selected stocks around the event day, it is necessary to quantify the return which exceeds expected return in announcement period or to calculate abnormal return. In event study the actual stock return is compared with expected stock return to determine whether the stock market reaction occurred. Daily stock price data in research are obtained from the web pages of Zagreb Stock Exchange ${ }^{2}$ (ZSE). Daily stock returns $\left(R_{i t}\right)$ are calculated by following expression:

$$
R_{i t}=\ln \left(\frac{P_{i t}}{P_{i t-1}}\right),
$$

where $P_{i t}$ stands for price of stock $i$ on day t, while $P_{i t-1}$ presents price of stock $i$ on day $t-1$.

Expected stock return on day $t\left(\mathrm{E}\left(\mathrm{R}_{\mathrm{it}}\right)\right)$ is calculated on the basis of market model and is based on the previous 30 daily returns data before the announcement period. The beta $(\beta)$ was calculated from a comparison period of 30 trading days prior to the announcement period. Expected stock return is calculated by following regression equation:

$$
E\left(R_{i t}\right)=\alpha_{i}+\beta_{i} R_{m t}+e_{i t} \text {. }
$$

$\mathrm{R}_{\mathrm{mt}}$ in equation 2 presents market return and it is calculated by following expression:

$$
R_{m t}=\ln \left(\frac{P_{m t}}{P_{m t-1}}\right),
$$

where $\mathrm{P}_{\mathrm{mt}}$ stands for daily point situation of CROBEX (official share index of ZSE) on day $t$ and $\mathrm{P}_{\mathrm{mt}-1}$ stands for point situation of CROBEX on day $t-1$. An abnormal return $\left(\mathrm{AR}_{\mathrm{it}}\right)$, which is calculating in announcement period, is calculated by following equation:

\footnotetext{
${ }^{2}$ www.zse.hr
} 


$$
A R_{i t}=R_{i t}-E\left(R_{i t}\right) \text {, }
$$

In order to test posed hypotheses it is necessary to test if the average abnormal returns for each group of stocks are statistically significant different from 0 . Average abnormal return $\left(\mathrm{AR}_{\mathrm{t}}\right)$ on day $t$ is calculated by equation 5 :

$$
A R_{t}=\frac{1}{n} \sum_{i=1}^{n} A R_{i t}
$$

Cumulative abnormal returns (CAR) are calculated by cumulating average abnormal return in announcement period.

\section{EMPIRICAL RESULTS}

In order to investigate the validity of the main hypothesis, it is necessary to investigate the influence of every direction of dividend announcement on stock price movement individually. Research starts with investigating unexpected dividend increase announcement on stock price. Results given by investigating the influence of unexpected dividend increase announcement on stock price is shown in the table 1 .

Table 1.

\begin{tabular}{|c|c|c|c|c|c|c|c|}
\hline \multirow{3}{*}{ Day } & \multicolumn{7}{|c|}{ Test value $=0$} \\
\hline & \multirow[t]{2}{*}{$\mathrm{t}$} & \multirow[t]{2}{*}{ df } & \multirow[t]{2}{*}{$\begin{array}{l}\text { Sig. (2- } \\
\text { tailed) }\end{array}$} & \multirow{2}{*}{$\begin{array}{c}\text { Mean } \\
\text { difference } \\
\text { (Abnormal } \\
\text { return) }\end{array}$} & \multirow[t]{2}{*}{ CAR } & \multicolumn{2}{|c|}{$\begin{array}{l}\text { 95\% Confidence } \\
\text { interval of the } \\
\text { difference }\end{array}$} \\
\hline & & & & & & Lower & Upper \\
\hline-7 & 0,152 & 34 & 0,88 & 0,073643 & 0,073643 & $-0,90946$ & 1,056741 \\
\hline-6 & 1,144 & 34 & 0,261 & 0,715146 & 0,788789 & $-0,55501$ & 1,985303 \\
\hline-5 & 1,347 & 34 & 0,187 & 0,641669 & 1,430457 & $-0,32653$ & 1,609871 \\
\hline-4 & 0,412 & 34 & 0,683 & 0,238969 & 1,669426 & $-0,94116$ & 1,419095 \\
\hline-3 & 1,476 & 34 & 0,149 & 0,517471 & 2,186897 & $-0,19516$ & 1,2301 \\
\hline-2 & 0,376 & 34 & 0,709 & 0,225277 & 2,412174 & $-0,9913$ & 1,441852 \\
\hline-1 & $-0,597$ & 34 & 0,555 & $-0,30735$ & 2,104823 & $-1,3539$ & 0,739199 \\
\hline 0 & 2,209 & 34 & 0,034 & 1,558823 & 3,663646 & 0,124533 & 2,993112 \\
\hline 1 & 0,184 & 34 & 0,855 & 0,102409 & 3,766054 & $-1,02586$ & 1,230677 \\
\hline 2 & $-0,856$ & 34 & 0,398 & $-0,43037$ & 3,335683 & $-1,45163$ & 0,590891 \\
\hline
\end{tabular}

Stock price reaction on dividend increase announcement

Dividend announcement day - day 0, (table 1) shows statistically significant stock price increase when compared to other days. Average abnormal return on the announcement day was $1,56 \%$. Positive abnormal stock return on the announcement day is statistically significant on a 5\% level. Other returns in the announcement days aren't statistically significant. Hence, we can draw a conclusion about accepting the first backing hypothesis $\mathrm{H}_{1.1}$.

Table 2 shows results of investigating the connection between the announcement of unexpected dividend decrease and stock price. 
Table 2.

\begin{tabular}{|c|c|c|c|c|c|c|c|}
\hline \multirow{4}{*}{ Day } & \multicolumn{7}{|c|}{ Stock price reaction on dividend decrease announcement } \\
\hline & \multicolumn{7}{|c|}{ Test value $=0$} \\
\hline & \multirow[t]{2}{*}{$\mathrm{t}$} & \multirow[t]{2}{*}{$\mathrm{df}$} & \multirow[t]{2}{*}{$\begin{array}{l}\text { Sig. (2- } \\
\text { tailed) }\end{array}$} & \multirow{2}{*}{$\begin{array}{l}\text { Mean } \\
\text { difference } \\
\text { (Abnormal } \\
\text { return) }\end{array}$} & \multirow[t]{2}{*}{ CAR } & \multicolumn{2}{|c|}{$\begin{array}{l}\text { 95\% Confidence } \\
\text { interval of the } \\
\text { difference }\end{array}$} \\
\hline & & & & & & Lower & Upper \\
\hline-7 & $-0,432$ & 10 & 0,675 & $-0,260555$ & 0.260 & $-1,60464$ & 1,083527 \\
\hline-6 & $-1,703$ & 10 & 0,119 & $-0,701482$ & $\begin{array}{c}- \\
0.962036\end{array}$ & $-1,61948$ & 0,216512 \\
\hline-5 & 0,047 & 10 & 0,963 & 0,024636 & $\begin{array}{c}- \\
0.937400\end{array}$ & $-1,13579$ & 1,185068 \\
\hline-4 & 0,073 & 10 & 0,943 & 0,046000 & $\begin{array}{c}- \\
0.891400\end{array}$ & $-1,36014$ & 1,452135 \\
\hline-3 & $-1,075$ & 10 & 0,308 & $-0,622955$ & $\begin{array}{c}- \\
1514354\end{array}$ & $-1,91413$ & 0,668224 \\
\hline-2 & $-1,152$ & 10 & 0,276 & $-0,705100$ & 2. & $-2,0693$ & 0,659097 \\
\hline-1 & $-2,173$ & 10 & 0,055 & $-1,244009$ & $\begin{array}{c}- \\
3,463464\end{array}$ & $-2,51932$ & 0,031303 \\
\hline 0 & 0,648 & 10 & 0,532 & 0,440255 & $\begin{array}{c}- \\
3.023209\end{array}$ & $-1,07325$ & 1,953764 \\
\hline 1 & $-1,068$ & 10 & 0,31 & $-1,237691$ & $\begin{array}{c}- \\
4,260900\end{array}$ & $-3,81866$ & 1,343275 \\
\hline 2 & 0,308 & 10 & 0,765 & 0,204636 & $\begin{array}{c}- \\
4,056264\end{array}$ & $-1,27718$ & 1,686457 \\
\hline
\end{tabular}

Unexpected dividend increase resulted in statistically significant positive abnormal return on the announcement day, whereas unexpected dividend decrease showed a statistically significant negative abnormal return on the day before a dividend announcement (day -1) which can be explained by information leakage. Abnormal return on the dividend decrease announcement day isn't statistically significant. On day-1 average abnormal return was $1,24 \%$ and is statistically significant on $10 \%$ level. The second backing hypothesis $\mathrm{H}_{1.2}$. is confirmed on the basis of the research made on the connection between unexpected dividend decrease and stock price.

Differently from unexpected increase or decrease dividend announcement which, according to hypothesis' assumption about dividend information content, should result in a significant stock price movement in the direction of announcement movement, maintaining the same level of dividends doesn't represent a significant information for investors. As stated above, announcement of payoff of the same dividend as the previous year shouldn't result in a statistically significant positive and negative stock price movement in the announcement period.

Results of the research of the connection between expected dividend announcement and stock price are shown in table 3 . 
Table 3.

Stock price reaction on unchanged dividend announcement

\begin{tabular}{|c|c|c|c|c|c|c|c|}
\hline \multirow{3}{*}{ Day } & \multicolumn{7}{|c|}{ Test value $=0$} \\
\hline & \multirow[t]{2}{*}{$\mathrm{t}$} & \multirow{2}{*}{ df } & \multirow{2}{*}{$\begin{array}{l}\text { Sig. } \\
(2- \\
\text { tailed) }\end{array}$} & \multirow{2}{*}{$\begin{array}{c}\text { Mean } \\
\text { difference } \\
\text { (Abnormal } \\
\text { return) }\end{array}$} & \multirow{2}{*}{ CAR } & \multicolumn{2}{|c|}{$\begin{array}{l}\text { 95\% Confidence interval } \\
\text { of the difference }\end{array}$} \\
\hline & & & & & & Lower & Upper \\
\hline-7 & 0,849 & 9 & 0,418 & 0,61251 & 0,61251 & $-1,01918$ & 2,244197 \\
\hline-6 & $-0,28$ & 9 & 0,786 & $-0,20747$ & 0,40504 & $-1,88332$ & 1,468379 \\
\hline-5 & 0,039 & 9 & 0,97 & 0,02713 & 0,43217 & $-1,56025$ & 1,614506 \\
\hline-4 & 0,539 & 9 & 0,603 & 0,42305 & 0,85522 & $-1,35206$ & 2,198155 \\
\hline-3 & 1,2 & 9 & 0,261 & 0,55268 & 1,4079 & $-0,48931$ & 1,594666 \\
\hline-2 & $-0,6$ & 9 & 0,563 & $-0,45446$ & 0,95344 & $-2,16677$ & 1,25785 \\
\hline-1 & $-0,144$ & 9 & 0,889 & $-0,10995$ & 0,84349 & $-1,84008$ & 1,620184 \\
\hline 0 & $-1,735$ & 9 & 0,117 & $-0,9432$ & $-0,09971$ & $-2,17279$ & 0,286387 \\
\hline 1 & 0,693 & 9 & 0,506 & 0,43331 & 0,3336 & $-0,98088$ & 1,847504 \\
\hline 2 & $-0,805$ & 9 & 0,441 & $-0,57606$ & $-0,24246$ & $-2,19386$ & 1,041743 \\
\hline
\end{tabular}

Announcement of the same dividend (table 3) as the previous year doesn't have a statistically significant influence on stock price movement on any day within the announcement period. Unchanged dividend doesn't represent statistically significant information for the market, which differentiates it from unexpected dividend increase or decrease announcement which concurs with signaling theory assumption. The third backing hypothesis $\mathrm{H}_{1.3}$ can be accepted based on the research made on unchanged dividend announcement influence.

Figure 2 shows cumulative abnormal stock returns for dividend increasing companies, dividend decreasing company and companies which have maintained the same dividend level. Figure 2 graphically confirms information value which dividend announcement has for investors. Graph shows the influence of dividend announcement direction on abnormal cumulative return of particular stocks.

Figure 2

\section{Cumulative abnormal stock returns}

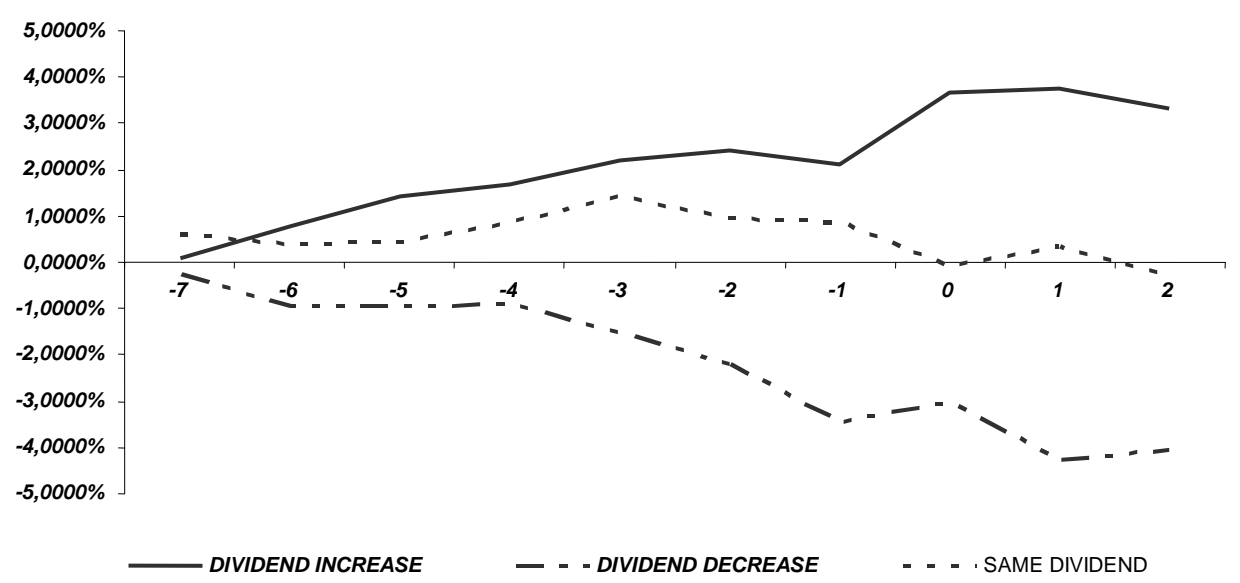


Stocks which announced an unexpected dividend increase, gained a positive 3.34\% abnormal cumulative return on the last day in announcement period. Stocks of companies which announced an unexpected dividend decrease gained a negative $-4.06 \%$ abnormal cumulative return, while group of companies which announced payoffs of unchanged dividends reported abnormal cumulative return of $-0,24 \%$. Abnormal cumulative return direction is the same as dividend announcement direction.

Based on previously confirmed backing hypotheses, abnormal cumulative return figure in announcement period, a conclusion can be drawn about confirming the main hypothesis of this paper that says:

\section{$H_{1}$ : Announcement of dividend change has significant value for investors on Croatian stock market.}

\section{CONCLUSION}

Research confirmed that dividend change represents a information relevant for market investors. Based on the shortage of information about company's present and/or future business, investors use management's dividend decisions as information upon which they question company's market value. If announced dividend is above expected, investors perceive this signal as positive information used by management to signal present and/or future company business. In case of positive information (dividend increase), company's stock price on dividend announcement day will increase above expected. If dividend announcement is below expected, investors perceive this as negative information used by management to signal present and/or future company business. In case of negative information, company's stock price on dividend announcement day will decrease below expected.

The empirical part of the paper examines the influence of unexpected dividend change in positive and negative direction as well as the influence of unchanged dividend announcement on stock price on the Zagreb Stock Exchange. Unexpected dividend increase announcement resulted in statistically significant stock price increase on the announcement day. Return gained on the announcement day was $1.56 \%$ higher than expected. Companies which announced unexpected dividend decrease showed statistically significant abnormal stock price decrease on the day before dividend announcement. Unexpected dividend decrease announcement resulted in return that was 1,24\% lower than the expected return. The connection between unexpected dividend increase and stock price increase is confirmed on $5 \%$ significance level, while the connection between unexpected dividend decrease and stock price decrease is confirmed on $10 \%$ significance level. The connection between unchanged dividend and stock price is not statistically significant which conforms to assumptions of dividend information content hypothesis that abovementioned information does not represent significant information for the investors.

\section{REFERENCES}

Abrutyn, S., Turner, R. W., (1990) “Taxes and firms' dividend policies: survey results”, National Tax Journal 43 (4): 491-497.

Asquith, P., Mullins jr., W., D., (1983), “The impact of initiating dividend payments on shareholders' wealth”, Journal of Business 56 (1): 77-96.

Capstaff, J., Klæboe, A., Marshall, P., A., (2004), "Share price reaction to dividend announcements: empirical evidence on the signaling model from the Oslo stock exchange”, Multinational Finance Journal 8 (1-2): 115-139. 
Denis, J., D, Denis, K., D., Sarin, A., (1994), “The information content of dividend changes: cash flow signaling, overinvestment, and dividend clienteles”, Journal of Financial and Quantitative Analysis 29 (4): 567-587.

Fuller, K., Goldstein, M., (2004), “Do dividends matter more in declining markets?”, [online], Available from: [http://ssrn.com/abstract=687067].

Gurgul, H., Majdosz, P., Mestel, R., (2006), "Implications of dividend announcements for stock prices and trading volume of DAX companies”, Finance a úverr - Czech Journal of Economics and Finance 56 (1-2): 56-68.

Haw, I., Kim, W., (1991), "Firm size and dividend announcement effect”, Journal of Accounting, Auditing \& Finance 6 (3): 325-344.

Healy, P. M., Palepu, K. G., (1998), "Earnings information conveyed by dividend initiations and omissions”, Journal of Financial Economics 21 (2): 149-176.

John, K., Lang, L., (1991), "Strategic insider trading around dividend announcements: theory and evidence”, Journal of Finance 46 (4): 1361-1389.

Johnson, K. H., (1998), “Graphical analysis for event study design”, Journal of Financial and Strategic Decisions 11 (1): 61-71.

Kalay, A., Loewenstein, U., (1986), "The information content of the timing of dividend announcements”, Journal of Financial Economics 16 (3): 373-388.

Lease, R. C., John, K., Kalay A., Loewenstein, U., Sarig., O. H., (2000), Dividend policy: its impact on firm value, (Harvard business school press).

Lintner, J., (1956), "Distribution of incomes of corporations among dividends, retained earnings and taxes”, American Economic Review 46 (2): 97-113.

Richardson, G., Sefcik, S., Thompson, R., (1986), "A test of dividend irrelevance using volume reactions to a change in dividend policy”, Journal of Financial Economics 17 (2): 313-334.

Petit, R. R., (1972), "Dividend announcements, security performance, and capital market efficiency”, Journal of Finance 27 (5): 993-1007.

\section{UTJECAJ OBJAVE DIVIDENDE NA KRETANJE CIJENA DIONICA U REPUBLICI HRVATSKOJ}

\section{SAŽETAK}

Cilj ovog istraživanja je ispitivanje veze između objave dividende i cijena dionica na hrvatskom tržištu kapitala uporabom metode studije događaja. Za period istraživanja uzet je period od početka 2007. godine do kraja 2009. godine. Rezultati istraživanja potvrdili su kako promjena dividende ima statistički značajnu vrijednost za ulagače na hrvatskom tržištu kapitala. Povećanje i smanjenje dividende rezultiralo je statistički značajnom promjenom cijena dionica u smjeru objave dividende dok objava očekivane isplate dividende nije rezultiralo statistički značajnom promjenom cijena dionica.

Ključne riječi: dividenda, objava dividende, cijena dionice, abnormalni prinos 